\title{
EquiLIBRIUM
}

Quarterly Journal of Economics and Economic Policy

2015 VOLUME 10 ISSUE 4, December

p-ISSN 1689-765X, e-ISSN 2353-3293

www.economic-policy.pl

Moszyński, M. (2015). Ordoliberalism and the Macroeconomic Policy in the Face of the Euro Crisis. Equilibrium. Quarterly Journal of Economics and Economic Policy, 10(4), pp. 41-58, DOI: http://dx.doi.org/10.12775/ EQUIL.2015.034

Michał Moszyński*

Nicolaus Copernicus University, Poland

\section{Ordoliberalism and the Macroeconomic Policy in the Face of the Euro Crisis}

JEL Classification: $B 25 ; E 61 ; H 12$

Keywords: Germany; macroeconomic policy; ordoliberalism; rules; economic order

\begin{abstract}
The global economic crisis and the crisis in the euro zone exposed the deep differences of opinion between German economists and scientists from AngloSaxon countries. The German approach conceptually differs in the views on the strategies and tools of anti-crisis policy, especially fiscal stimulus in the Keynesian-style, quantitative easing monetary policy of the ECB, the question of financial assistance to Greece and restructuring its debt. The other areas of difference are the approach to the rules in macroeconomic policy, fiscal consolidation, and interpretation of current account surplus. Given the size and performance of the German economy it is important to understand the reasons for these opposites, which constitute the research goal of this article. Considerations are based on the thesis that ordoliberal thought still has a strong impact on the practice of macroeconomic policy in Germany and also at the European level. The analysis is built on the short overview of ideological foundations of the German social market economy and its most important postulates, which then will be applied for interpretation of intellectual distinctions between economists from Germany and other countries in the theoretical and practical dimensions of the economic policy observed in Eu-
\end{abstract} Toruń

(C) Copyright Institute of Economic Research \& Polish Economic Society Branch in

Date of submission: January 23, 2015; date of acceptance: August 28, 2015

* Contact: moszyn@umk.pl, Nicolaus Copernicus University, ul. Gagarina 13a, 87-100 Toruń, Poland 
rope. The methodology includes the critical literature studies and the comparative analysis of macroeconomic policy through the prism of economic thought.

\section{Introduction}

The crisis in the euro zone and the earlier 2007-2008 global financial crisis has highlighted the differences between the position of Germany and other countries including international organizations (Balcerzak, 2009a, pp. 257274). The points of disagreement concern not only macroeconomic policy instruments to help overcome the recession but also its intellectual foundations, European design and European institutions. One can indicate in brief: a reluctance to stimulate the economy by Keynesian-type instruments, policy based on rules, philosophy of politics at the level of economic order and the primacy of monetary policy. Given the dominant economic and political position of Germany in Europe, these differences are crucial for resolving the euro zone crisis and for the process of further integration. Their understanding require looking through the prism of economic theory in historical perspective. The line of argumentation is based on the assumption that the ordoliberal thought still exerts a strong influence on the practice of macroeconomic policy in Germany and at the European level as well. This is due to the fact that the ordoliberal ideas still make the intellectual base for the great part of decision-makers and influential economists in Germany. In the literature this is referred to as the "long shadow" cast by ordoliberalism (Dullien \& Guérot, 2012). Only in 2005 some authors (Allen, 2005, pp. 199-221) indicated that the German ordoliberalism indeed won the war against Keynesianism, but it may be influenced by Anglo-Saxon version of neoliberalism. Meanwhile, in the face of the problems in the euro zone, it turned out that the representation of ordoliberal ideas is so strong that their representatives have a position of a player with veto power, blocking other solutions (Young, 2015, pp. 78-90). Germany has adhered to the principles of its policy for a long time and today's disputes represent a new development of debate held throughout the period after World War II.

The paper consists of three main parts. Firstly, the main theses of ordoliberalism are outlined which are juxtaposed with the proposals of Keynesianism as two competing doctrines of post-war Germany's economics and economic policy. Then the main areas of conflict between German economists and the representatives of Anglo-Saxon mainstream economics are collected. The implications of these differences for macroeconomic policy in the context of the euro zone crisis will be the subject of the third part. The study ends up with a set of conclusions. 


\section{Method of the Research}

The paper is based on the critical study of literature and analysis of economic doctrines, mainly ordoliberalism, Keynesianism and - to a lesser degree - monetarism. Contemporary discussion on macroeconomic policy is interpreted as a continuation of the historically conditioned binding of economics with the practice of economic policy. For a better understanding of the relative autonomy of German economic thought some components of historical analysis and comparative analysis of macroeconomic policy were used. To illustrate the main areas of dispute, the major theses of representatives from the ordoliberal and Anglo-Saxon circles were quoted.

\section{Ordoliberalism versus Keynesianism in Economic Thought and Economic Policy of Post-war Germany}

Economists and lawyers from the stream of ordoliberal thought already in the 1930s asked the question about the desirable shape of the economic order and called for a strong, but limited, in terms of decision-making, state. Its main task would be to create and to guard an economic order, within the framework of which smooth market processes could occur. They stood at the same time in opposition to unbridled laisse-fair capitalism and collectivism. After the second world war the Keynesianism was regarded by them as an interventionist doctrine that can lead to socialism, which in turn would mean, in accordance with the title of the famous work of Hayek Road to Serfdom, the loss of freedom. Both German business and a federal minister of economics L. Erhard were reluctant about Allies' administrative approach to the economy and promoted the most liberal policy in Europe under the banner of the Social Market Economy (SME). The "new liberals" (a term coined by A. Rüstow) from Freiburg school, already having a ready proposal for the political system, implemented main elements of their program forming the basis of West German economic order. Admittedly, SME model, built on the basis of ordoliberal demands for years of L. Erhard's tenure (1948-1966), was subject to significant evolution over time, but politics in post-war Germany was oriented consistently on a few key objectives:

- the primacy of monetary policy according to the Euckenian constitutive principle of competitive order,

- opening the German economy to the global markets, which would absorb German exports, 
- the promotion of market competition through the creation of institutional framework of competitive economic order,

- limitation of the scope of state intervention and the desire to use the instruments in line with market logic (marktkonform).

To understand today's debate on the objectives and tools of the macroeconomic policy, one should get to know the place and role of Keynesian ideas in the post-war economic history of Germany. It turns out they have never taken roots enough to get a lasting impact on the thinking of economic and political elites of this country. In the development of Keynesianism in the science of economics in post-war West Germany several main stages can be distinguished (Bombach et. al., 1985, pp. 9-17). Friction between Keynesianism and ordoliberalism set certain development stages of SME model in Germany.

The first phase of Keynesianism, which lasted until 1956, included a traditional concept of demand-side measures in the sense of overall control, which has been developing in clear opposition to the ordoliberal approach, represented mainly by Eucken, Erhard and their proponents. In the macroeconomic policy these ideas have not been reflected due to the dominant position of the CDU party, which was a carrier of ordoliberal program.

In the second phase the centre-left Social Democratic Party (SPD) and the trade unions (DGB) tried to implement the policy of economic stimulation in their programs. During a period of full employment achieved in the early sixties they were convinced that this is a good tool for a time of inevitable decline. In 1965 Germany survived the first post-war recession, which opened the way for political changes, among other things Erhard's resignation from the office of Federal Chancellor in December 1966. This enabled the social democratic politician K. Schiller to introduce the Stability and Growth Law in 1967 (Stabilitäts- und Wachstumsgesetz). During this period, the academic world fully turned towards Keynesian and neoclassical synthesis in the US version, which, however, quickly raised concerns. The law officially imposed on government implementation of the "magic rectangle" including: full employment, price stability, steady growth and external balance. Schiller argued that the government is just concerned about the macroeconomic indicators, but on the microeconomic level the players will continue to enjoy full freedom in conducting their activities. He described the new policy with the famous formula "Synthesis of Keynesian message with the Freiburg imperative" (Synthese der Keynesianischen Botschaft mit dem Freiburger Imperativ).

The turn of the sixties and seventies and the next decade were characterized by a paradigm change - a shift towards monetarism and the renewal of conviction that the market mechanism could ensure full employment, with 
the support of efficient system of flexible prices. SPD never ruled with an absolute majority, so its coalition partners always slowed fuller implementation of Keynesian policies. Highly independent Bundesbank was manned by economists with monetarist inclination and taking over the position of finance minister after the resignation of Schiller in 1972 by H. Schmidt and his subsequent governance reversed Keynesian tendencies. German economists clearly emphasized that the country's economic problems are of a structural - not cyclical - nature, thus the use of Keynesian instruments was not justified.

Since the late 1970s, after the experience of oil crises, there was a return to the idea of a policy of economic order (Ordnungspolitik). In the mid-80s the government of Chancellor Kohl referred to the origins of SME and postulated its renewal. In 1992 Kohl (1992, pp. 193-196) claimed that the post-war boom years have weakened the foundations of economic order and the economy has become less resistant to crises, as evidenced by the inability of curbing unemployment in the 70s. For Kohl a macroeconomic policy mistake was to underestimate the pernicious impact of inflation on economic growth and employment, which leads to the conclusion about the impossibility of unrestrained influence over the economic situation. In the context of the crisis - according to Kohl - a consistent policy in the spirit of Erhard is reliable, which includes:

- priority to the stability of the value of money,

- sound public finances,

- priority to generate income against its division,

- prosperity for all, both entrepreneurs and employees.

For Kohl, the SME was a proven concept, still up-to-date and worth developing. The state should not play a dominant role in the labour market, and the German model of social partnership, in which tariff partners decide on pay and working conditions, contributes greatly to the efficient functioning of the economy and improvement in the labour market.

A number of trends and ideas contributed to limitation of the acceptance of the Keynesian concepts in Germany:

- The fear that Keynesianism will contribute to the build-up of inflationary pressures and lead to the intervention spiral. Inflation aversion was established by the hyperinflation of the 1920s.

- Successful currency reform of 1948, which inaugurated the restrictive monetary policy of the independent Bundesbank.

- The high acceptance for the model of industrial relations, highly autonomous of direct state intervention (Allen, 2005, pp. 204).

- Reluctance to determine the numerical targets for economic growth, typical for "hydraulic" version of Keynesianism. 
- The dominance of conservative centre-right parties, long periods of governance and stability of personnel - a small staff rotation at the highest levels of government.

The weakness of Keynesianism also stemmed from the fact that the intellectual elite around the circle of Freiburg ordoliberals was able to create a convincing alternative that was based largely on the accumulated experience reaching the nineteenth century and brought unprecedented growth in the 1950s.

\section{The Clash of Ideologies - the Main Areas of Conflict Between German and the Anglo-Saxon Approach}

The main areas of conflict between German and Anglo-Saxon economists can be reduced to a few points. These controversies are not always fully articulated, some can be treated as elements of the ideology ${ }^{1}$ deeply rooted in the subconscious mind, which filters the world perception. As Denzau and North (1994) explained, ideas and ideologies shape the subjective mental structures through which individuals interpret the world and make economic and political decisions. According to the well-known Keynes' statement, ideas have the powers that rule the world, therefore the awareness of these differences allow a deeper interpretation of the economists' position in the German- and English-speaking countries.

The following list (table 1.) should be considered as a set of stylized facts that may be of course subject of a separate discussion. Naturally, the dividing line between economists of German and Anglo-Saxon origin is conventional. The two groups are not fully homogeneous, and the differences nevertheless correspond to national boundaries. Inside the circles of German economists disputes are also being held regarding the modern macroeconomic policy in the face of the crisis, although $\mathrm{P}$. Bofinger, a long year member of influential Council of Economic Experts, stated meaningfully, that he himself has been the last Keynesian in Germany (The Economist, 2015b). The list of differences neither explores deeper the well-

${ }^{1}$ J. Godłów-Legiędź (2014, p. 21-22) indicates that in the process of creation of economic knowledge the worldview plays an important role. Systems of economic views, even considered as products of an objective reason and called theories, take the form of ideology. On the basis of neoliberalism, Keynesianism and other concepts, the researchers are based on certain assumptions concerning the nature of economic phenomena, whose genuineness they cannot be quite sure of. For an economist going beyond the pure description and interpretation of the studied phenomena in the direction of policy marks the transition from positive to normative economics, which is necessarily based on the elements of evaluation and assessment. 
known points, dividing neoclassical and Keynesian ideas nor exposes the differences among models of capitalism in the varieties of capitalism approach.

Table 1. The main areas of divergence between the German and Anglo-Saxon economics

\begin{tabular}{|l|l|l|}
\hline \multicolumn{1}{|c|}{ Area } & \multicolumn{1}{|c|}{ German economics } & \multicolumn{1}{|c|}{ Anglo-Saxon economics } \\
\hline $\begin{array}{l}\text { The preferred type of } \\
\text { economic policy }\end{array}$ & $\begin{array}{l}\text { The primacy of policy of } \\
\text { economic order }\end{array}$ & Process policy \\
\hline Time horizon & Long & Short \\
\hline Policy basis & Rules & Discretion \\
\hline $\begin{array}{l}\text { The objectives } \\
\text { of economic policy }\end{array}$ & Price stability & $\begin{array}{l}\text { The fight against } \\
\text { unemployment }\end{array}$ \\
\hline Social security & $\begin{array}{l}\text { Complementary and not } \\
\text { contradictory to the growth } \\
\text { strategy }\end{array}$ & $\begin{array}{l}\text { Weakens the incentives for } \\
\text { efficiency and growth }\end{array}$ \\
\hline $\begin{array}{l}\text { The pace of economic } \\
\text { growth }\end{array}$ & $\begin{array}{l}\text { Reluctance to setting numer- } \\
\text { ical goals }\end{array}$ & $\begin{array}{l}\text { The desired rate set as } \\
\text { a goal }\end{array}$ \\
\hline $\begin{array}{l}\text { Aggregation of economic } \\
\text { categories }\end{array}$ & $\begin{array}{l}\text { Reluctance to aggregation, } \\
\text { through which the structure } \\
\text { is lost }\end{array}$ & $\begin{array}{l}\text { Aggregation as a transition } \\
\text { from the micro to the macro } \\
\text { level }\end{array}$ \\
\hline $\begin{array}{l}\text { Achieving an economic } \\
\text { equilibrium }\end{array}$ & $\begin{array}{l}\text { Helping to achieve an equi- } \\
\text { librium by coordination of } \\
\text { the main social actors }\end{array}$ & $\begin{array}{l}\text { State intervention may be } \\
\text { necessary to achieve } \\
\text { a balance }\end{array}$ \\
\hline Anti-crisis policy* & Structural reforms & $\begin{array}{l}\text { Fiscal or monetary expan- } \\
\text { sion }\end{array}$ \\
\hline $\begin{array}{l}\text { The directions of public } \\
\text { expenditure * }\end{array}$ & $\begin{array}{l}\text { Preference of investment to } \\
\text { consumption }\end{array}$ & $\begin{array}{l}\text { Consumption as a motor for } \\
\text { growth }\end{array}$ \\
\hline $\begin{array}{l}\text { Interpretation of the } \\
\text { surplus in the trade } \\
\text { balance* }\end{array}$ & $\begin{array}{l}\text { Surplus as an expression of } \\
\text { competitiveness }\end{array}$ & $\begin{array}{l}\text { The surplus as a result } \\
\text { beggar-the-neighbour poli- } \\
\text { cy; debt of trading partners }\end{array}$ \\
\hline
\end{tabular}

* In the case of German economic policy the elements of the process policy complement the policy of economic order.

Source: own elaboration.

An important distinction having its roots in ordoliberalism is the distinction between the policy of economic order (Ordnungspolitik) and the process policy (Prozesspolitik). According to the orthodox view of the Freiburg school the role of the state is to create an institutional framework for the economic process, rather than to interfere directly in this process with policy instruments. In this way a neoclassical belief becomes visible that the market mechanism is able to generate good results, if an appropriate institutional framework is created. The main ordering power is a mecha- 
nism of flexible prices and the strength of competition, best captured by the title of the American edition of the book of L. Erhard "Prosperity for all" translated as "Prosperity through competition". Policy of economic order, by definition, is focused on the long term, and therefore requires consistency and patience. According to the ordoliberal thesis about the interdependence of economic phenomena (Interdependenzthese), all actions taken by the state to a greater or lesser extend impact on the overall economic order and should therefore be coherent and logically complement each other. Therefore, state interventions within the process policy should be kept to a minimum, and if already taken, only by measures consistent with the logic of the market (marktkonform). There is clearly recognizable divergence between ordoliberal and Keynesian thinking, which by definition was focused on the short term, and monetarism alike, which also suggested the process policy, but more by means of monetary policy ${ }^{2}$.

These differences are related to the desire of grounding policy on rules rather than discretionary decisions. An order rests upon the principles, and the rules structure the behaviour of market participants, stabilize expectations and increase market transparency. Examples of preference of rulesbased approach are visible both on the national level and in the construction of an institutional order of the EU, which will be discussed below.

A policy based on rules relates to the principle of responsibility, which in practice is manifested by the emphasis on the obligations of debtors, dislike of excessive debt, policy stability etc. The views grounded in the German economic thought in the days of the Freiburg school are still present. In this context it is worth quoting the statement of Otmar Issing, a former chief economist of the Bundesbank and the ECB, provoked by an opinion of the special "systemic role of banks" in the economy. He stated that "If banks or states are not allowed to go bankrupt, principles of the market economy will be undermined. Who, therefore, put the whole system into question, has understood nothing." Moreover, the market as a "discovery procedure" must possess methods of rewarding effective behaviour and punishing failure (Issing, 2011).

Another area of differences is the preference between the two "bads" in macroeconomic policy - inflation and unemployment. Inflation aversion, inherited after the hyperinflation from the 1920s, led Germany to tolerating rather high unemployment, while conducting parallel restrictive monetary policy. Different preference is particularly important in the context of monetary union with countries of Southern Europe, traditionally preferring lower unemployment. In the classic textbook De Grauwe (2005, pp. 13-15)

${ }^{2}$ The resemblance between Keynesianism and monetarism on the area of the process policy is stressed by P. Pysz (2010, pp. 68-69). 
raises this issue, pointing out that freezing the exchange rates in the monetary union between such different countries like Germany and Italy narrows the choice between inflation and unemployment. Currency issues were in the centre of the Euckenian model of the competitive economic order. The primacy of monetary policy constitutes its basic principle, since, as argued Eucken, it is impossible to build a competitive economic order without sound money. He cites (probably after Schumpeter) in this context a sentence attributed to Lenin "in order to destroy bourgeois society you must debauch its money." (Eucken, 2004, pp. 255). Prices must correctly fulfil the function of the measures of resources scarcity, and in addition they must be stable. Already quoted Issing (2000) clearly represents this position and associates price stability with the ECB independence and constant concern about its credibility. Only the primacy of monetary policy can provide a stable euro, and hence successful European integration.

With regard to the stimulating the economy during crises the Germans prefer to strengthen the supply side of the economy through investment and policy of economic order. It has to create a basis for long-term economic growth in contrast to short-term growth stimulation by consumption (Balcerzak \& Rogalska, 2014, pp. 88-93; Balcerzak, 2008, pp. 181-204). In the German culture saving is a virtue, and how "The Economist" points out (2015), “...what others call "austerity”, Germans call Sparpolitik, "savings policy", which has a much more positive connotation." In the background of such thinking is the Say's law of markets, proclaiming that supply creates its own demand and the national income accounting savingsinvestment identity. This strategy is complemented by the demand for structural reforms to increase the competitive potential of the economy, the emphasis on increased productivity that in turn determine the acceptable average wage growth (Balcerzak, 2009b, pp. 71-106). Linking wages with productivity has been postulated by the politics since the time of Erhard and strongly accented by the Bundesbank, trying to indirectly influence wage negotiations. An example of such wage self-discipline is an informal "pact for jobs" observed in 2000-2009 (Lesch, 2010), when unit labour costs remained stable, and effective wages developed in line with the pace set by the tariff partners.

The strategy of export-led growth, implemented successfully by Germany, generating large surplus in the balance of trade and current account balance, is interpreted by German economists as a sign of the competitiveness of goods "made in Germany". By contrast, this strategy is subjected to criticism by the Anglo-American economists as a beggar-the-neighbor policy. Martin Wolf (2013) concluded that „,...a large country with a huge structural current account surplus does not just export products. It also ex- 
ports bankruptcy and unemployment, particularly if the counterpart capital flow consists of short-term debt." Similarly, the US Treasury (2013) criticized Germany for maintaining too large surplus in the current account, "Germany has maintained a large current account surplus throughout the euro area financial crisis, and in 2012, Germany's nominal current account surplus was larger than that of China. Germany's anaemic pace of domestic demand growth and dependence on exports have hampered rebalancing at a time when many other euro-area countries have been under severe pressure to curb demand and compress imports in order to promote adjustment. The net result has been a deflationary bias for the euro area, as well as for the world economy."

In the ordoliberal tradition the economic growth has not been fetishized, it has obviously mattered, but as a category resulted from free economic process. Specifying in advance by the government a desired economic growth rate would be associated with constructivism. In Germany, economic growth as the goal of macroeconomic policy was adopted not until short period of flirting with the Keynesian ideology in the before mentioned Stabilization and Growth Law in 1967. Operating on the macroeconomic aggregates (e.g. global demand, total savings and investments), especially developed by Keynes and his followers, leads to a loss of specificity of individual market segments and bears the risk of missing problems of their correct structure, what already stressed Eucken and Röpke. According to M. Burda, this reluctance among German economists is still visible: "Ordoliberalism's biggest flaw, lies in "failing to do the aggregation step. It is at heart a microeconomic model that disavows macroeconomic policy because it treats countries, or even an entire currency zone, as if they were individual households." (The Economist, 2015b).

In the Anglo-Saxon countries the generous social security system is often regarded as an obstacle in raising efficiency due to the weakening incentives, whereas in Germany since the time of Bismarck, it is assumed that the social capitalism helps to stabilize the social status of employees (Sennett, 2006, pp. 30-31). Complex coordination tools of the social partners (the close links between the large companies and banks financing them, cooperation between employers' organizations and trade unions) support the market mechanism in achieving general economic equilibrium and sometimes in a more or less formal manner strengthen the government strategy. In contrast, Keynesian theory warily assess the ability of the private sector of the economy to achieve stability automatically, and this sector is considered as the source of fluctuations that destabilize the entire economy and lead to cyclical unemployment. 
Some elements in German economic thinking are a legacy from the industrialization period of the nineteenth century. One can point a preference of investment as a source of economic growth, expanded model of social security complementary to growth strategy and a coordinated model of industrial relations. The survival of these fixed points for such a long period provides an indication of strong phenomenon of path dependence.

In the German academic world, thinking in terms of economic order is still present and passed on to the next generation of economists. In the German standard textbooks on macroeconomics and political economy the issues of economic order are at least mentioned, while in their English counterparts - totally absent.

Ordoliberal ideas are represented by a large part of the intellectual and political elites in Germany (Mączyńska \& Pysz, 2014). The examples are: the German Central Bank, the Federal Ministry of Finance, the Federal Ministry for Economic Affairs and its Academic Advisory Board (Wissenschaftlicher Beirat), the Council of Economic Experts (Sachveständigenrat) and industry and employers' associations. From the outside, it may seem that ordoliberalism dominates the thinking of the German elite, but conservative circles, related to e.g. yearbook "ORDO" and the Walter Eucken Institute, are of the opinion that a far-reaching drift has taken place moving away the practice of economic policy from the original Erhard's Social Market Economy.

\section{Practical Implications for Macroeconomic Policy in the Face of the Euro Zone Crisis}

Some of the outlined postulates of ordoliberal stream have been successfully implemented at the European level. It can be exemplified by the institutional framework of competition ${ }^{3}$ and monetary policy. For Germany the resignation of the D-Mark was conditioned by creation of institutional and functional copy of the Bundesbank by the ECB, especially its high degree of independence and objectives of monetary policy. The Bundesbank in Germany attached great importance to the issue of wages and tried to influence indirectly the wage bargaining. At the European level, the ECB does not have such tools except monetary policy tightening and thereby threatening to cause the unemployment. The problem are the lack of coordination

\footnotetext{
${ }^{3}$ The impact of Eucken thought can be traced in the records of the Treaty establishing the European Economic Community in 1957 relating to the competition rules in the European common market, repeated later in the Treaty on the Functioning of the European Union in Lisbon in 2008. The influence is huge, but underrated.
} 
of monetary and fiscal policy, which remains in the responsibility of member states, and various forms of wage bargaining. That is why Germany sought to provide some patterns of behaviour of fiscal policy in a highly heterogeneous group of countries within the EU by imposing the rules of the Stability and Growth Pact. The very design of monetary union assumed to limit an excessive fiscal expansion by the Pact, on which Germany pushed. It can be assumed that for Germany it would not be necessary and was pushed through with a view to less disciplined countries. Although Germany was in a situation of an excessive deficit procedure in 2002-2007 and 2009-2012, however, since budget year 2011 the public debt brake (Schuldenbremse) has operated written down in the Constitution. However, in the light of breaking the rules of the Pact, Germany pushed through the adoption of the fiscal compact, which is based on balanced budget rules, a debt brake rule and an automatic correction mechanism. Finally, the Treaty of Maastricht enshrined the no-bail-out rule, which prohibits taking over responsibility for the debts of individual member states by the authorities of the EU and other member states.

Since the outbreak of the financial crisis disagreements have emerged about the mitigation of its consequences. A different vision of Germany on crisis management in the euro area meant that they have become particularly evident.

In Anglo-Saxon countries the teaching of Keynes returned (R. Skidelsky even titled his 2009 book "Keynes. Return of the Master"), but while in the US, both Republicans and Democrats implemented a stimulus package, in Germany this policy was introduced with considerable hesitation. Eventually, the federal government launched a package worth 50 billion euros in January 2009. Including the earlier program of tax cuts from autumn of 2008 it was 80 billion, which must be regarded as an exceptionally strong reaction, considering that the federal government have practically never launched the typical expansionary Keynesian-style policies stimulating the economic situation ${ }^{4}$, regardless of whether it was about the national economy or the European economy. German reluctance to fiscal expansion has been criticized by many American economists, especially P. Krugman.

\footnotetext{
${ }^{4}$ The period of transformation of the former German Democratic Republic can be considered as an exception. The process absorbed enormous resources from the federal budget and shifted the budget balance into the deficit and in the long run increased public debt by approx. 20 percentage points. As a result of this expenditure Germany came into recession later than other countries. Government spending was directed at rebuilding the infrastructure, thus they can be interpreted as strengthening the supply side of the economy, and not the deliberate stimulation of aggregate demand.
} 
Germans are seen to have a position of hegemon and stabiliser in Europe, but in the face of the crisis German politicians stressed the need for self-responsibility of each country and reluctantly accepted the role of a leader. Relatively weak domestic demand inhibits the role of the growth engine for the countries of Southern Europe (Poirson \& Weber, 2011). Some authors claim that the benefits for Germany from participating in the euro area are so high that in their own interest Germany should financially help in real adjustments the Eurozone countries that have problems, and that previously constituted market for German goods (Posen, 2011). After creating a monetary union, countries of the south fell into a kind of debt trap, lured by the progressive convergence of nominal interest rates, which were falling to the German level.

The view repeatedly expressed by Germany, that the cause of the problems in southern European countries, especially Greece, are of a structural nature, therefore structural adjustments are needed (Schäuble, 2015), became the subject of criticism by the IMF (2013), according to which the level of adjustment is too high. Germans after 25 years of financing of the former GDR are very sceptical about the success of supporting other countries, especially if there are large structural mismatches. The unification entailed reforms that the public associate with sacrifices, cuts in wages and changes in the labour market. Having experienced such problems make Germans expect readiness for sacrifice from the others ${ }^{5}$. Moreover, a similar approach is also represented by the Baltic States and Slovakia, whose small open economies linked to the euro have survived the acute recession since 2008. Impossibility of nominal exchange rate devaluation forced them to painful internal devaluation. The weak euro due to the crisis improved situation in the German trade balance and on the labour market, and therefore there was no need to take exceptional measures to stimulate the economy.

The main line of argument of the German decision-makers can be summarised as follows: wasteful and undisciplined governments will not be able to keep a balanced budget during the boom, which restricts their room for manoeuvre during the recession. There is no guarantee that the support bailout substantially changes their behaviour. This means the moral hazard at the expense of German taxpayers, which would be contrary to the German constitution. The German Federal Constitutional Court (Bundesverfassungsgericht), empowered and with great authority, signalled its objections to the proposed transfer of competences in the area of fiscal supranational level. This represents a significant obstacle to the possible taking over fi-

${ }^{5}$ Such a hypothesis is put forward by A. Newman (2015, pp. 117-135.) 
nancial commitments of other countries ${ }^{6}$. That is why Germany did not agree to issue Eurobonds, or to provide joint guarantees for financial assistance. These arguments clearly expounded Finance Minister W. Schäuble (2012), who stated: "Moral hazard is not benign. Setting the wrong incentives would mean stabbing reformist governments in the back. By suggesting that uncompetitive economic structures can endure, we would buoy the populists (...). By discouraging reform, we would not solve Europe's imbalances but make them permanent. (...) If we want to maintain such a level of protection in a rapidly changing world, we must ask ourselves where the wealth to sustain it will come from. Not from a euro-zone budget, the printing press or Eurobonds. All of our economies, not just a few, will have to generate this wealth, and they can only do so if they adapt to the rigors of a hyper-competitive world economy. Prosperity is not a Godgranted right - it must be earned." In this context Schäuble has the full support of the Bundesbank, whose President, J. Weidmann, often refers to Eucken, the main ordoliberal thinker, and translates the principle of responsibility for the functioning of the institutional order of the euro area. Weidmann (2012) voiced criticism, among others, about ECB policy easing, consisting in buying up securities of dubious quality, what raises the question of possible joint responsibility of member states, especially in the absence of appropriate control mechanisms at EU level. According to him accountability and control are of crucial importance for the institutional framework of monetary union.

Schäuble also represents the position of the majority of German economists on monetary policy when he warns "that monetary policy cannot substitute for fiscal and structural reforms in member countries (...). Monetary policy can only buy time." (Schäuble 2015). Minister's consistent attitude enjoys a high degree of recognition in society, and his policy was supported by about 70\% of the respondents in July 2015 (Afhüppe, Steingart 2015).

\section{Conclusions}

The conducted analysis of the importance of ordoliberal thinking in postwar Germany argues that it has had a tremendous impact on the shape of the economic order of Social Market Economy as well as on macroeconomic policy. The real influence of Keynesianism as the main competitive doc-

\footnotetext{
${ }^{6}$ In 2012 H.-W. Sinn, a leading German economist, declared himself as ordoliberal, initiated an open letter signed by 172 professors of economics who warned about extending liability for the state debts „Frankfurter Allgemeine Zeitung” (2012).
} 
trine had persisted for only a short period of time and did not become the dominant school of thought among the German elite.

Historically conditioned ordoliberalism domination, or at least its elements, in the German economy raises a lot of differences in views between German and Anglo-Saxon economists, or more broadly, from the "rest of the world", on how the economy really works, the role of the state and its macroeconomic policy.

Disagreements highlighted by the financial crisis and the crisis in the euro area lead to specific decisions (or the lack of them) at the levels of national and European economies. It is unlikely that these differences will be quickly balanced out. This raises legitimate concerns about the euro zone, which has always been a political project, and its construction does not take sufficient account of the achievements of economic theory ${ }^{7}$. Such situation that Greece happened to be trapped into was also not foreseen, thus, the procedures for leaving the euro zone were not established. This means that politics and economics will grapple with these challenges for a long time, and the intellectual base of discussion on the German side will still be set, consciously or subconsciously, by the ordoliberal ideology.

The course of future discussion emerged in July 2015. Minister Schäuble proposes to reduce some of the powers of the European Commission (enforcement of the EU law implementation, supervision of the common market), handing them over to the independent state agencies modelled on the German Federal Cartel Office (Bundeskartellamt). It would be a manifestation of the so-called "regulatory capitalism" (Braithwaite, 2008), a fairly typical German solution. He argues that the Commission cannot be both "Guardian of the Treaties" and act according to EU rules, and, on the other hand, to pursue a discretionary policy like a government (Frankfurter, 2015). President Hollande's proposal to deepen integration through the creation of government for the euro zone, fiscal and political union (Wiegel, 2015) raises the question of on what basis should it resist. In the context of analysed ideological differences it would be questionable. One commentator expressed it as follows: "The differences between the German ordoliberal concept of fiscal policy and the French Keynesian one are irreconcilable. Berlin wants a watertight system of rules that strips policymakers of discretion, whereas for Paris economic and political discretion are paramount. (...). But ordoliberalism cannot work as a governing principle for a currency union with different intellectual traditions and divergent economies." (Legrain, 2015).

\footnotetext{
${ }^{7}$ It is mainly about the convergence criteria, which does not have much in common with the theory of optimum currency areas. Germany in the 90 s put a lot of emphasis on meeting the convergence criteria as a condition for entry into the monetary union.
} 
The desire to base economic policy on rules becomes more understandable, considering the federal structure of Germany. The more the constitution of the country concerned is similar to the federation, the more rules are needed for its proper operation ${ }^{8}$. It is worth noting that the historical cases of federal countries meeting with the economic success were associated with a stable, rules-based monetary policy. At the end of the twentieth century these were: the US, Germany and Switzerland. Since the structure of the monetary union in many ways is a federal one, expectations of Germany, to develop it on the basis of rules becomes more understandable.

M. Burda, the American economist working for years in Berlin, said that "Ordoliberalism is not very practical, it's religion" (The Economist, $2015 b$ ). From the perspective of Germany one can respond with a title of Kant's work (1793), it is a "Religion within the Bounds of Bare Reason".

\section{References}

Afhüppe S. \& Steingart G. (2015). Kanzler der Vernunft. Handelsblatt, 24-26.07. Allen, Ch. S. (2005). "Ordo-Liberalism” Trumps Keynesianism: Economic Policy in the Federal Republic of Germany and the EU. In: B. H. Moss (Ed.). Monetary Union in Crisis The European Union as a Neo-liberal Construction. New York: Palgrave MacMillan.

Balcerzak, A. P. (2009a). Przeglad i wstęna ocena teoretycznych stanowisk dotyczacych źródet globalnego kryzysu gospodarczego. In: S. Antkiewicz, M. Pronobis (Eds.). Gospodarka w warunkach kryzysu. Warszawa: Wydawnictwo Naukowe CeDeWu.pl.

Balcerzak, A. P. (2009b). Wptyw działalności regulacyjnej państwa $w$ obszarze kreowania ładu konkurencyjnego na rozwój nowej gospodarki. In: A. P. Balcerzak, M. Moszyński (Eds.). Aktywność regulacyjna państwa a potencjat rozwojowy gospodarki. Toruń: Polskie Towarzystwo Ekonomiczne Oddział w Toruniu.

Balcerzak, A. P. (2008). Współczesna polityka stabilizacyjna wobec problemów informacyjnej nieefektywności decydentów gospodarczych: przypadek Stanów Zjednoczonych. Zeszyty Naukowe Polskie Towarzystwo Ekonomiczne, 6.

Balcerzak, A. P. \& Rogalska E., (2014). Crowding Out and Crowding in within Keynesian Framework: Do We Need Any New Empirical Research Concerning Them?. Economics \& Sociology, 7(2). DOI: 10.14254/2071-789X.2014/7-2/7.

Bombach, G., Netzband, K. B., Ramser, H.-J. \& Timmermannet, M. (Eds.) (1983). Der Keynesianismus IV, Die beschäftigungspolitische Diskussion in der Wachstumsepoche der Bundesrepublik Deutschland. Berlin, Heidelberg, New York: Springer-Verlag.

\footnotetext{
${ }^{8}$ This issue is stressed by an American historian H. James (2015).
} 
Braithwaite J. (2008). Regulatory Capitalism, How it Works, Ideas for Making it Work Better. Cheltenham, Northampton: Edward Elgar.

De Grauwe, P. (2005). Economics of Monetary Union, 6th ed. New York: Oxford University Press.

Denzau, A. T. \& North, D. C. (1994). Shared Mental Models: Ideologies and Institutions. Kyklos, 47(1), http://dx.doi.org/10.1111/j.1467-6435.1994.tb 02246.x

Die Aktualität Euckens, Ein Gespräch zwischen Ernst-Joachim Mestmäcker und Walter Oswalt. In: Eucken (2004). Grundsätze der Wirtschaftspolitik, Mohr Siebeck. Tübingen.

Dullien, S. \& Guérot U. (2012). The Long Shadow of Ordoliberalism: Germany's Approach to the Euro Crisis. ECFR, 49.

Eucken, W. (2004). Grundsätze der Wirtschaftspolitik. Tübingen: Mohr Siebeck.

Frankfurter Allgemeine Zeitung (2015) Schäuble will EU-Kommissionentmachten. 30.07 .

Frankfurter Allgemeine Zeitung (2012). Der offene Brief der Ökonomen im Wortlaut, 05.07.

Godłów-Legiędź, J. (2014). Ideologia liberalna i keynesowska z perspektywy globalnego kryzysu. In: P. Pysz, A. Grabska \& M. Moszyński (Eds.), Ład gospodarczy a wspótczesna ekonomia. Warszawa: PWN.

International Monetary Fund (2013). Greece: Ex Post Evaluation of Exceptional Access under the 2010 Stand-By-Arrangement. IMF Country Report, 13/156.

Issing, O. (2000). Walter Eucken: vom Primat der Währungspolitik, Lecture at The Walter-Eucken-Institut. Retrieved from https://www.ecb.europa.eu/press/key/ date/2000/html/sp000317_2.de.html (20.06.2015).

Issing, O. (2011). Der Weg in die Knechtschaft. Frankfurter Allgemeine Zeitung, 11.12 .

James, H. (2015). Teutonische Obsessionen. Handelsblatt, 05.08.

Kant, I. (1793). Die Religion innerhalb der Grenzen der bloßen Vernunft. Königsberg: Friedrich Nicolovius.

Kohl, H. (1992). Bilanzen und Perspektiven, Regierungspolitik 1989-1991, Band 1. Bonn: Presse- und Informationsamt der Bundesregierung.

Legrain, P. (2015). The Last Thing the Eurozone Needs Is an Ever Closer Union. Foreign Policy 31.07. Retrieved from https://foreignpolicy.com/2015/07/ 31/france-plan-eurozone-integration-is-a-bad-idea. (31.07.2015).

Lesch, H. (2010). Lohnpolitik 2000 bis 2009 - Ein informelles Bündnis für Arbeit. IW-Trends, 1.

Mączyńska, E. \& Pysz, P. (2014). Liberalizm, neoliberalizm i ordoliberalizm. Ekonomista, 2.

Moszyński, M. (2013). Problemy teorii i polityki konkurencji w myśli ordoliberalnej. Ekonomia i Prawo, 12(2). DOI: http://dx.doi.org/10.12775/EiP.2013.017.

Newman, A. (2015). The Reluctant Leader. Germany's Euro Experience and the Long Shadow of Reunification. In: M. Matthijs, M. Blyth (Eds.). The Future of the Euro. Oxford: Oxford University Press. 
Poirson H. \& Weber S. (2011). Can Germany be Europe's engine of growth? Retrieved from http://www.voxeu.org/article/can-germany-be-europe-s-enginegrowth, (15.07.2015).

Posen, A. S. (2011). The Euro Payoff: Germany's Economic Advantages from a Large and Diverse Euro Area. Peterson Institute for International Economics. Retrieved from http://www.iie.com. (30.07.2015).

Pysz, P. (2008). Społeczna gospodarka rynkowa. Ordoliberalna koncepcja polityki gospodarczej. Wydawnictwo Naukowe PWN, Warszawa.

Pysz, P. (2010). Komplementarność i synteza koncepcji polityki gospodarczej Waltera Euckena i Ludwiga Erharda. In: E. Mączyńska, P. Pysz (eds.). Idee Ordo i Społeczna Gospodarka Rynkowa. Warszawa: Polskie Towarzystwo Ekonomiczne.

Schäuble, W. (2012). Building a Sturdier Euro. The euro's original design created lopsided incentives for its weakest members. Wall Street Journal, Retrieved from www.wsj.com/articles/SB10001424127887323981504578174812451337 $722(03.06 .2015)$.

Schäuble, W. (2015). Wolfgang Schäuble on German Priorities and Eurozone Myths. New York Times, Retrieved from www.nytimes.com (15.04.2015).

Sennett R., (2006). The Culture of the New Capitalism. London: Yale University Press, New Haven.

„The Economist” (2015a). Austere? Your word, not ours. 18.07.

„The Economist” (2015b). Germany and economics, of Rules and Order. 09.05.

US Treasury Department (2013). Report to Congress on International Economic and Exchange Rate Policies. 30.11.

Weidmann J. (2012). Finanzsystemstabilität und nachhaltiges Wachstum. Retrieved from www.bundesbank.de/Redaktion/DE/Reden/2012/2012_11_29_weid mann_finanzstabilitaet.html (20.07.2015).

Wiegel M. (2015). Hollande will eine „Wirtschaftsregierung“ für Europa. Frankfurter Allgemeine Zeitung. 14.07.

Wolf, M. (2013). Germany's strange parallel universe. www.ft.com, 24.09.

Young, B. (2015). The battle of ideas in the Eurozone crisis management German ordoliberalism versus post-Keynesianism. In: S. Fadda P. Tridico (Eds.). The Economic Crisis in Social and Institutional Context Theories, policies and exit strategies. London, New York: Routledge. 


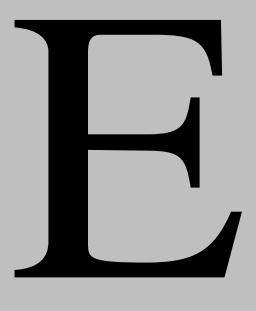

Q U I L I B R I U M

Quarterly Journal of Economics and Economic Policy

\section{Institutional Determinants of Macroeconomic Effectiveness}





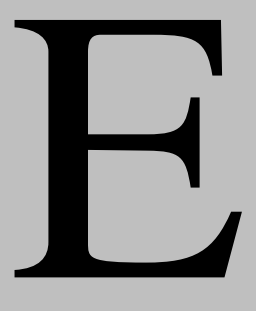

Q U I L I B R I U M

Quarterly Journal of Economics and Economic Policy

\section{Institutional Determinants of Macroeconomic Effectiveness}


